\title{
In Our Time: \\ Civil Rights, Women's Liberation, and Jewish-Christian Dialogue Fifty Years After Nostra Aetate
}

Katharina von Kellenbach, Saint Mary's College of Maryland

Nostra Aetate has rightly been called a "revolution" and is celebrated as a giant step in the path toward JewishChristian reconciliation and interreligious dialogue. ${ }^{1}$ Its passage at the Second Vatican Council in 1965 was the culmination of the work of concerned Christians and Jews who were determined to draw lessons from the tragedy of the Holocaust and to put an end to centuries of Christian "teaching of contempt." Beginning in 1947 in Seelisberg, Switzerland, theological activists both lay and ordained, created an ecumenical and interreligious movement of Protestants, Catholics, and Jews who came together in dialogue and laid the seeds to reimagine the relationship between the Old and of the New Israel. At the Council, in heated clashes over politics and theology, the passage of Nostra Aetate was so unlikely that it can be considered a miracle. But it passed, and became the impetus for profound theological changes.

Following Roy Eckardt's Black-Woman-Jew: Three Wars for Human Liberation, ${ }^{3}$ I want to place Nostra Aetate into the historical context of the 1960s, where Jewish demands for respect were raised alongside and amidst the American civil rights movement, global anti-colonialist liberation struggles, and the women's movement. It is no accident that Abraham Joshua Heschel marched on Selma with Martin Luther King

\footnotetext{
'John Connolly, From Enemy to Brother: The Revolution in Catholic Teaching on the Jews, 1933-1965 (Cambridge: Harvard University Press, 2012).

'Jules Isaac, The Teaching of Contempt: The Christian Roots of AntiSemitism (New York: Holt, Rinehart and Winston, 1964).

${ }^{3}$ Roy Eckardt, Black-Woman-Jew: Three Wars for Human Liberation, (Bloomington: Indiana University Press, 1989).
} 
in the same year, 1965, as he met with Pope Paul VI to advocate for Nostra Aetate. Among the fifteen official female "auditors" who were allowed to attend Vatican II were several nascent feminist theologians, among them Sister Mary Luke Tolbin and Rosemary Goldie, as well as Mary Daly.

The 1960 s was a revolutionary decade that challenged the ideologies and institutions that had ordained the secondary and inferior status of Jews, Blacks, women, the colonized, the poor, and the young. The language of liberation and revolution, of emancipation and freedom, of equality and civil rights infused this decade with hopes and dreams. With confidence, Nostra Aetate proclaims that

No foundation therefore remains for any theory or practice that leads to discrimination between individual and individual or people and people, so far as their human dignity and the rights flowing from it are concerned. The Church reproves as foreign to the mind of Christ, any discrimination against people, or harassment of them because of their race, color, condition of life, or religion.” (NA §5)

"In Our Time" was written at a propitious moment in history that generated visions of a future in which songs of "we shall overcome" rang to announce the end of discrimination, inequality, and oppression. The democratic paradigm shift that was cautiously embraced by Vatican II and pushed through in the political battles of the 1960s and 1970s released enormous theological creativity and saw the flourishing of feminist theology, Jewish-Christian dialogue, as well as liberation, black, and womanist theology. These theological movements challenged

\footnotetext{
${ }^{4}$ Carmel McEnroy, Vatican II: Guests in Their Own House (New York: Crossroads, 1996). Sister Tobin was one of the fifteen female auditors at Vatican II and a feminist theologian; see "Female and Catholic: An interview with Sister Mary Luke Tobin, S.L., U.S. Catholic, originally appeared in April 1987 issue, now available online at http://www.uscatholic.org/church/2012/09/female-and-catholic-interviewsister-mary-luke-tobin-sl? page $=0 \% 2 \mathrm{C} 0$.
} 
conventional hierarchies that elevate one gender, one race, and one religion over another, and generated new theological models to respect difference, value equality, and embrace pluralism. Scholars and activists explored the theological implications of granting full humanity to women, human dignity to slaves and the colonized, and theological value to the distinctive paths of Jews and Gentiles (Gal 3:28). But even as egalitarian theologies of liberation on the basis of gender, race, class, and religion gained a foothold in academia and mainline churches, the center of the political debate and popular culture shifted.

It is not only that conservative parties have come into power, beginning with the elections of Ronald Reagan (1981), Margaret Thatcher (1979), Helmut Kohl (1982), and the appointment of Pope John Paul II (1978). But rather, the topics of public debate shifted so as to sideline progressive theological scholarship. To give an example: Increasingly, the first question I receive after delivering a lecture on Christian theological anti-Judaism concerns the state of Israel. The speaker challenges me-often in a hostile tone-to take a position on Zionism and the Middle East conflict. But my lecture did not concern the Middle East, I am no expert in that part of the world, and have little to contribute to the resolution of the Israeli-Palestinian conflict, let alone the wars raging among and with neighboring countries. But the frequency of such experiences has convinced me that the discussion of Christian theological supersessionism has been impacted, if not hijacked, by the rise of new political discourses.

Political scientist Vesla M. Weaver has proposed the concept of "frontlash" to explain the dynamics by which the terms of a political debate are changed. Her theory does not neatly fit across the disciplines or my three areas of theological concern: feminist theology, black theology, and theology in the Jewish-Christian dialogue. But I want to use her theory to show how it is possible that-fifty years after Nostra Aetatechurch and political leaders pay homage to principles of gender, racial, and religious equality while at the same time 
pursuing policies that aim to curb and control the power of women, Jews, and Blacks.

\section{From Race to Crime}

In her provocative article, "Frontlash: Race and the Development of Punitive Crime Policy," Weaver argues that the Civil Rights Act of 1964 defeated the beneficiaries of legal segregation in the South. But it did not end racism. While the Civil Rights Act of 1964 imposed norms of racial equality, its attendant civil disobedience and the inner city riots allowed segregationist politicians to recast the political debate by linking race with crime. Weaver provides historical evidence that shows how opponents of civil rights regrouped and developed new political and legal initiatives to raise police budgets, toughen sentencing guidelines, and construct new prisons. The new emphasis on "law and order" created double binds for liberal politicians and garnered public support for policies that would eventually result in the mass incarceration of Black Americans. Weaver introduces the term "frontlash" to explain the coincidence of rising concern over crime at a point in time when the civil rights movement effectively challenged the political structure of white supremacy:

I advance the notion of frontlash, or the process by which losers in a conflict become the architects of a new program, manipulating the issue space and altering the dimension of the conflict in an effort to regain their command of the agenda. Frontlash hinges on the presence of winners and losers of a recent political conflict... By maneuvering into a new issue space and carving a new niche to mobilize around, the disadvantaged/defeated group opens the possibility of reversing its fortunes without violating established norms.

Vesla M. Weaver, "Frontlash: Race and the Development of Punitive Crime Policy," Studies in American Political Development 21 (Fall 2007): 23-265, 236. 
Weaver concludes her historical review with the felicitous phrase: "the graveyard of civil rights legislation was the same place where crime bills were born. ${ }^{\circ}$ The recognition of racial equality as the new norm and law of the land became the platform which permitted the focus of tough-on-crime initiatives on communities of color. Weaver insists that this political shift was not the result of a "redneck" backlash but the work of think tanks and cultural elites that worked strategically to recoup the loss of power and influence in the aftermath of civil rights legislation:

The key distinction then between frontlash and backlash consists in both the nature of the political reaction and the actors, which carry that reaction to its conclusion. Backlash is reactive in a conservative dimension (aims to preserve the status quo and resist changes through emboldened opposition). Importantly, the main actors of consideration are the masses, the voting population that prompt elites to undertake certain policy positions with race in the foreground. Frontlash is preemptive, innovative, proactive, and, above all, strategic. Here, elites aim to control the agenda and resist changes through the development of a new issue and appropriation and redeployment of an accepted language of norms... Instead of a bungee cord recoiling when stretched too far, we can think of frontlash as water moving swiftly through a path that eventually comes to an end, forcing the water to seek alternative routes or as a weed that after being killed by weed killer mutates into a new variety, becoming resistant. It is strategic, alive, complex and sophisticated in its reaction. $^{7}$

One needs to beware of conspiracy theories here. But Weaver's contention that political strategies are planned and implemented by agents who possess the educational means

${ }^{6}$ Ibid., 265.

${ }^{7}$ Ibid., 238.

SCJR 10 (2015) 
and economic resources to influence public opinion and shape public policy is well taken. The five hundred percent increase in the prison population over the last thirty years did not occur accidentally or inadvertently. Of the 2.4 million citizens the United States currently incarcerated, a staggering sixty percent are people of color. ${ }^{8}$ Mass incarceration maintains the economic and political structures of white supremacy without ostensibly violating the norms and laws of racial equality. It is certainly ironic to realize that just as racism was normatively and legislatively repudiated in the United States, Black Americans found themselves the target of crime fighting measures that led to unprecedented levels of incarceration and the loss of life, liberty, property, and dignity of millions of people.

While the statistics on mass incarceration are particular to the United States, the impact of police violence on communities of color is a global reality. Taking The New York Times from the hot summer of 2015 as an example, one finds reports of riots in the aftermath of deadly police arrests from Israel, Netherlands, and Brazil. ${ }^{9}$ In all of these news stories, race and crime are intertwined and political commitments to racial, religious, and ethnic equality clash with police tactics that fight crime by aggressively controlling Black and immigrant communities.

The concept of frontlash captures the innovative search for new language to repackage ideas that have been delegitimized. In Europe, the ideology of racism was defeated on the battlefields of World War II and in the overthrow of

\footnotetext{
${ }^{8}$ American Friends Service Committee, "Facts about the mass incarceration of people of color in the U.S.," June 19, 2013, https://afsc.org/story/facts-about-mass-incarceration-people-color-us

${ }^{9}$ Isabel Kershner, "Anti-Police Protest in Israel Turns Violent," New York Times, 4 May, 2015, A7; Simon Romero and Taylor Barnes, "Despair, and Grim Acceptance, over Killings by Brazil's Police, New York Times, 22 May, 2015, A1; Mike Corder, "The Hague Hit by Riots After Death of Man in Police Custody," Associated Press, 3 July, 2015, http://bigstory.ap.org/article/b3fc00c087414ce0a989f8bb1fb65c59/haguehit-riots-after-death-man-police-custody.
} 
National Socialism. But nationalist movements, such as Pegida (Patriotic Europeans Against the Islamization of the Occident $)^{10}$ or Front National in France, regularly stoke racial and religious anxieties. Such movements take pains to distance themselves from discredited codes of nationalism (vs. patriotism), racism (vs. Islamization), and antisemitism (vs. the West). It is only under these new banners that popular support can be mobilized in order to control "foreigners" and curb presumed threats emanating from racial and religious others. Weaver rightly warns against underestimating these movements as mere backlash phenomena made up of "redneck" or "neo-Nazi" rabble. While her article traces the careers and involvement of segregationists in the development of crime-fighting law and order policies, I am mostly interested in the potential of her theory to highlight the role of intellectuals in recreating credible racial arguments and the resilience of structures that are invested in national, racial, or religious supremacy.

In this article, I am also making claims about the presence of a frontlash in the movements for gender and JewishChristian equality. I will not be able to provide sufficient empirical evidence to document the particular agents of frontlash, which risks charges of conspiratorial thinking. Conspiracy theories are especially rife in discussions of antisemitism. While I don't argue for the existence of a cabal of cigar-smoking men, I do argue that we should assume the existence of strategic thinking on the part of agents who resist democratic principles of equality and try to reclaim political ground in the aftermath of the victory of egalitarian movements.

\section{From Gender to Pro-Life}

Nostra Aetate does not address gender inequality and does not renounce discrimination on the basis of gender or

\footnotetext{
${ }^{10}$ Patriotic Europeans Against the Islamisation of the Occident (translated from the German: Patriotische Europäer gegen die Islamisierung des Abendlandes).
} 
sexuality. But the presence of female auditors at the Second Vatican Council heralded the beginnings of the women's movement within the Church/es. "The women of Vatican II" concludes Carmel McEnroy "were convinced that they had turned the corner in terms of being accepted as full human beings and full church members. There was no going back." "1 But, McEnroy notes,

although the movement ... was quickening ... it was almost a stillbirth in terms of actual movement for women within the church, after the conciliar euphoria died down, although women's spirits continued to rise, and they began to hear one another to speech in theological and pastoral circles. ${ }^{12}$

Of the multiple levels in which the subordination and silencing of women continues within the church, the exclusive use of the language of "fathers," "brothers," and "sons" is only the most obvious and jarring symptom. But even among the most recalcitrant representatives of the hierarchy, open endorsements of women's secondary and inferior status have become anathema and are understood to be politically disadvantageous and theologically problematic. Grudgingly, prescriptive role assignments for the "eternal woman" (singular), who was to submit to her God-given role in service to husband, children, and the church had to be amended. Most Christian churches (albeit not all) pay homage to the fundamental equality of women. But, at the same time, a striking political mobilization has occurred that generates enormous emotional energies and reasserts the primacy of principle over the individual personhood of women. Already Pope John XXIII had feared that women's equality and economic independence might affect women's willingness to submit to childbearing and childrearing:

\footnotetext{
${ }^{11}$ McEnroy, Guests, 265.

${ }^{12}$ Ibid., 42.
} 
But even if the economic independence of women brings certain advantages, it also results in many, many problems with regards to their fundamental mission of forming new creatures! Hence we have new situations that are serious and urgent... These arise in the area of family life: in the care and education of youngsters, in homes that are left without the presence of someone that they need so much; in the loss of disturbance of rest resulting from the assumption of new responsibilities; and above all in keeping feast days holy, and in general, in fulfilling those religious duties which are the only thing that can make a mother's work of training her children really fruitful. ${ }^{1}$

While church leaders have been forced to accept women's professional involvement as a result of economic changes, the political battle over women's equality shifted into bruising debates over women's access to contraception and abortion. This transfer into the intimate arena of sexuality and reproduction gives rise to deeply held emotions, fears, and desires that serve to cloud the personal and social realities of childbearing and childrearing. Instead of engaging with women who make responsible and informed decisions about motherhood and rearing new generations amidst complex personal, economic, and political circumstances, the pro-life movement politicized, idealized, and scandalized women's choices. The movement was conceived by political and religious elites in the aftermath of the Supreme Court's Roe v. Wade decision in 1973. As Weaver points out:

Rather than defend the status quo ante then, losers propose new programs of action. By maneuvering into a new issue space and carving a new niche to mobilize around, the disadvantaged/defeated group opens the

\footnotetext{
${ }^{13}$ Quoted by Christine Gudorf in "Contraception and Abortion in Roman Catholicism," Sacred Rights: The Case for Contraception and Abortion in World Religions, ed. Daniel Maguire (New York: Oxford University Press, 2003), 65.
} 
possibility of reversing its fortune without violating established norms. ${ }^{14}$

The equation of women's sexual and reproductive choices with murder and mass murder created a powerful new matrix that provided, in the words of Weaver, "issue dominance ... [and] a monopoly on the understanding of an issue, associating it with images and symbols while discrediting competing understandings." ${ }^{15}$ The designation of abortion as murder served to silence and shame women, who are portrayed as selfish and immature, in need of guidance and counseling, and who cannot be trusted to make moral choices affecting their bodies and children. ${ }^{16}$ While many women have joined the pro-life movement, its leaders hail from U.S. Catholic Bishops Conference as well as from conservative Protestant evangelical circles. ${ }^{17}$ Ronald Reagan was among the first to compare abortion to the Holocaust, a trope that has since then mushroomed and infiltrated the official statements of numerous church leaders. ${ }^{18}$ This movement, born in the "two

\footnotetext{
${ }^{14}$ Weaver, "Frontlash,” 236.

${ }^{15}$ Ibid.
}

${ }^{16}$ Thirty eight states in the United States have passed fetal homicide laws and prosecute women for miscarriages and/or refusal to submit to caesarean sections. See National Conference of State Legislatures, http://www.ncsl.org/research/health/fetal-homicide-state-laws.aspx.

${ }^{17}$ Jerry Reiter, Live from the Gates of Hell: An Insider's Look at the Antiabortion Underground (Amherst, NY: Prometheus Book, 2000); James Risen and Judy Thomas, The Wrath of Angels: The American Abortion War (New York: Basic Books, 1998); Kristin Luker, Abortion and the Politics of Motherhood (Berkeley, CA: University of California Press, 1984); and Ziad Munson, The Making of Pro-life Activists: How Social Movement Mobilization Works (Chicago: University of Chicago Press, 2002).

${ }^{18}$ Ronald Reagan, Abortion and the Conscience of the Nation (Nashville, TN: Human Life Foundation, 1983); John Powell, SJ, Abortion: The $S_{\text {- }}$ lent Holocaust (Allen, TX: Argus Book 1981); Randall A. Terry, $A$ Humble Plea to Bishops, Clergy, and Layman: Ending the Abortion Holocaust (Insurrecta, 2008); and Katharina von Kellenbach, "Notes on ChrisChristian Resistance to the "Abortion Holocaust" in Lived Religion and the Politics of (In)Tolerance, ed. Srđan Sremac (New York: Palgrave Macmillan, forthcoming). 
epicenters in the USA and Rome," has become a global phenomenon, as Andrzej Kulczycki has shown in his comparative analysis of reproductive policy campaigns in Mexico, Poland, and Kenya. ${ }^{19}$

The Manhattan Declaration was released on November 20, 2009 and originally signed by 168 Roman Catholic, Protestant, and Orthodox religious leaders, including seventeen Roman Catholic bishops and seven women, two of whom co-signed as wives of pastors. It became the platform for an ecumenical movement to organize against abortion, gay rights and health care reform and calls on churches, religious communities, and individuals to engage in civil disobedience in defense of "the sanctity of human life, the dignity of marriage as a union of husband and wife, and the freedom of conscience and religion." ${ }^{20}$ The signers draw on the authority of Dietrich Bonhoeffer and Martin Luther King and call for civil disobedience to "roll back the license to kill that began with the abandonment of the unborn to abortion" and to uphold a "healthy marriage culture" rooted in the "sexual complementarity of man and woman."

The document argues that feminism leads to the disintegration of the family and to the rise in divorce rates and male violence in and outside the family, to child abuse, sexual promiscuity, and the delinquency of children. Even "genocide and "ethnic cleansing" seem to "flow from the same loss of the sense of the dignity of the human person and the sanctity of human life that drives the abortion industry." Most insidious are comparative assertions that claim that the "abortion holocaust" claims more victims than Jews murdered by Nazi Germany. ${ }^{21}$ The Manhattan Declaration blames the "culture of

\footnotetext{
${ }_{19}$ Andrzej Kulczycki, The Abortion Debate in the World Arena (New York: Routledge, 1999), 27.

${ }^{20}$ Manhattan Declaration, http://www.Manhattandeclaration.org.

${ }^{21}$ A google search on "abortion" and "holocaust" returns more than 2 million entries. Organizations increasingly have names like "www.survivors.la" (suggesting that every person alive is a survivor of abortion); or
}

SCJR 10 (2015) 
death," which began with the legalization of abortion as the source of "social pathologies of every sort," including delinquency, drug abuse, crime, incarceration, hopelessness, and despair. The Manhattan Declaration became the blueprint for the U.S. Catholic Bishop's Conference "Year of Prayer" in 2012, in which they invited

Catholics to pray for rebuilding a culture favorable to life and marriage and for increased protections of religious liberty... The call to prayer is prompted by the rapid social movements and policy changes currently underway, such as the mandate by the U.S. Department of Health and Human Services that coerces employers, including heads of religious agencies, to pay for sterilizations, abortion-inducing drugs and contraceptives, as well as increased efforts to redefine marriage. ${ }^{22}$

A subsequent frontlash was already built into the document of 2009 and has since been implemented in the aftermath of the Supreme Court's striking down the ban on gay marriage. As soon as discrimination of homosexuality was declared illegal, the public speech of resistance shifted from gay marriage to the protection of religious freedom. While it is individuals like the Kentucky county clerk Kim Davis, or florists or bakers in Indiana who capture the news, their actions cannot be understood apart from the strategic matrix developed by religious leaders who used their considerable intellectual and economic resources to mobilize around new categories.

Using the language of civil disobedience and solidarity with the oppressed and vulnerable, pro-life campaigns aim to

www.babykaust.de, which argues that abortion constitutes a genocide against "German babies" and exceeds the number of Jewish victims.

${ }_{22}$ "Bishops Urge Catholics to Pray for Life, Marriage, Religious Liberty," Dec. 6, 2012, United States Conference of Catholic Bishops, http://www.usccb.org/news/2012/12-212.cfm. 
elevate the legal rights of embryos over the physical integrity and moral agency of women. The focus on the unborn creates a wedge between women and children and contests women's responsibility to make prudent and moral choices. Weaver's frontlash theory exposes the organized and top-down nature of this shift that intended to reverse the achievements of the women's movement without contravening new linguistic conventions. Abortion, like crime, is a serious moral and theological topic, but it has been sensationalized and instrumentalized by frontlash campaigns that question the moral agency of women and the integrity of Black people and prevent dialogue and genuine conversation. The conflation of race with crime and of women's rights with reproductive rights shifted the terms of the debate into emotionally fraught and ambiguous territory. Characterizing women as murderers and Blacks as criminals provides justification to reassert patriarchal control by state and church. Abortion has become a toxic topic, not least in U.S. politics, which is facing another round of budget negotiations that threaten a government shutdown over the proposal to defund Planned Parenthood. The introduction of abortion into any conversation inflames tempers and raises the temperature in the room. The irrational, contradictory, and passionate quality of these debates undermines genuine conversations about the complexity of childbearing and -rearing and instead channels deep anxieties over men's loss of control over women's reproductive power.

The terms "sexism" and "racism," just as "antisemitism," have become loaded and polemic fight words. But we should consider reclaiming these words as diagnostic terms that refer to structures and ideologies that aim to control and contain the power of women, Blacks, and Jews, who continually threaten the privilege and preeminence of Gentile male heads of households. Despite enormous challenges and changes to this kyriarchy over the last fifty years, the data on wealth distribution and political power arrangements point to 
the resilience and adaptation of this system. ${ }^{23}$ Frontlash campaigns protect structures of privilege and refuse to engage women or Blacks as equals as they struggle with motherhood and crime in poor neighborhoods. Instead, frontlash creates new ideological tropes that transport emotional anxieties that arise from the loss of control and hegemony. The emotional arousal that attends the politics of abortion and of crime is only rivaled by contemporary debates over Zionism.

\section{From Anti-Judaism to the State of Israel}

The movement to accept Judaism as a theologically valid and equal faith tradition, which began with Nostra Aetate, is confronted by the explosive rise of emotionally fraught debates over the legitimacy of Zionism and the politics of the state of Israel. As befits the history of antisemitism, these debates do not break down neatly along political divisions of left and right, progressive and conservative. On the contrary, mainline Christian denominations, which have endorsed the principles of Jewish-Christian dialogue, find themselves consumed by petitions to boycott, divest, or sanction companies doing business in or with Israel. Israel has moved onto the agendas of the Presbyterian Church (U.S.A.), ${ }^{24}$ the United Church of Canada, ${ }^{25}$ United Church of Christ in the United States, ${ }^{26}$ the Evangelical Lutheran Church in America, ${ }^{27}$ as well

\footnotetext{
${ }^{23}$ Elisabeth Schüssler Fiorenza, "Introduction: Exploring the Intersections of Race, Gender, Status, and Ethnicity in Early Christian Studies," in Prejudice and Christian Beginnings: Investigating Race, Gender, and Ethnicity in Early Christian Studies, Laura Nasrallah and Elizabeth Schüssler Fiorenza eds. (Minneapolis: Fortress Press, 2009), 1-23.

24 “2014 General Assembly Divestment List," Presbyterian (U.S.A), http:/www.pcusa.org/resource/2014-general-assembly-divestment-list/.

${ }_{25}^{25}$ "United Church of Canada Policies on Israel and Palestine," United Church of Canada, http:/www.united-church.ca/files/generalcouncil/gc41/israel-palestine-policy-summary.pdf.

${ }^{26}$ At its 30th General Synod taking place in June 2015 in Cleveland the UCC passed a resolution to boycott and divest from companies that profit from Israel's occupation of Palestinian lands by an overwhelming majority. See United Church of Christ Palestine/Israel Network website, "United Church of Christ Votes to Boycott \& Divest from Companies Profiting
} 
as the progressive Catholic peace organization Pax Christi, among others. On the other end of the theological and political spectrum, one finds evangelical Christian churches that maintain active missionary programs and hold that Jews are consigned to eternal damnation unless they convert to Christianity, but profess loyalty to Israel's governmental politics and entreat their followers to "please pray for Israel's continued protection and peace." ${ }^{28}$ The theory of frontlash may explain why Christians who renounce theological supersessionism are more open to anti-Zionist sentiments than Christians who integrate Zionism and the state of Israel into a Christian triumphalist salvation history.

Like abortion and crime, the discussion of the IsraeliPalestinian conflict is complex and demands factual analysis, historical and political knowledge, and empathetic dialogue. The politics of frontlash, on the other hand, sensationalizes and dramatizes controversies in order to prevent dialogue and pragmatic compromise. Rhetorical denunciations of Zionism as racism, Israel as an apartheid state, and Israeli soldiers as Nazis reinforce postures of contempt. But so do Christian Zionist visions of a militarized Israel as a "catalyst for the end of times." Wheaton professor Gary Burge correctly points out that "the crown jewel in Christian Zionism's world view" is the belief that "the birth of Israel has now set the stage for the imminent second coming of Jesus." ${ }^{30}$ But he wrongly charges Christian Zionists with abandoning replacement theology,

from Israel's Occupation,” Press Release, June 30, 2015, http://www.uccpin.org/\#!pressrelease/c1a36.

${ }^{27}$ Evangelical Lutheran Church in American, "'BDS': What does the ELCA say?"

http://download.elca.org/ELCA\%20Resource\%20Repository/PNW_elca_ bds.pdf.

${ }^{28}$ Chosen People Ministries, "Evangelism" http://chosenpeople.com/main/index.php/evangelism/400-the-church-andjewish-evangelism.

${ }^{29}$ Gary M. Burge, "Evangelicals and Christian Zionism," in Zionism and the Quest for Justice in the Holy Land, eds. Donald E. Wagner and Walter T. Davis (Eugene, OR: Wipf and Stock, 2014), 175-190: 178.

${ }^{30}$ Ibid., 186. 
which he notes "has been an historic teaching of the church and has never been considered a heresy. ${ }^{\text {"31 }}$ By incorporating the state of Israel into Christian dispensationalist salvation history, Christian Zionists are not necessarily moving beyond theological supersessionism. On the contrary, this position affirms that the covenantal promises in the Old Testament are fulfilled in the New Testament and that the universal message of Christianity has supplanted the election of Israel. Typically, pro-Zionist Christian support is couched in supersessionist terms, as for instance, by the Messianic Jewish Bible Institute (MJBI):

We are committed to the centrality of Yeshua and the power of the Holy Spirit ... We are committed to a continued Jewish lifestyle that is rooted in Torah and applied in the New Covenant. The Jewish heritage, where it is in accord with the letter and the Spirit of the New Covenant, is fostered. In Israel, this is especially connected to the return to the land in a Hebrew language society in conjunction with Romans 11:29 [emph added]. ${ }^{32}$

The websites of Jews for Jesus ${ }^{33}$, Arbeitsgemeinschaft für das Messianische Zeugnis an Israel ${ }^{34}$, Evangeliumsdienst für Isra$\mathrm{el}^{35}$, Lausanne Consultation on Jewish Evangelism ${ }^{36}$, Internationale Christian Embassy in Jerusalem ${ }^{37}$ call for demonstrations of solidarity in prayer and travel, in national and church politics, while resisting calls to end proselytism or to enter into Jewish-Christian dialogue. Evangelical declara-

\footnotetext{
${ }^{31}$ Ibid., 188.

${ }^{32}$ Messianic Jewish Bible Institute, mjbi.org/Israel/.

${ }^{33}$ Jews for Jesus, jewsforjesus.org (in English); judenfuerjesus.de (in German).

${ }^{34}$ Arbeitsgemeinschaft für das Messianische Zeugnis an Israel, amzi.org.

${ }^{35}$ Evangeliumsdienst für Israel, evangeliumsdienst.ktweb.eu.

${ }^{36}$ Lausanne Consultation on Jewish Evangelism,

lcje.net/upcomingconferences.html.

${ }^{37}$ Internationale Christian Embassy in Jerusalem, de.icej.org (in German); int.icej.org (in English).
} 
tions such as the 1989 Willowbank Declaration combine proZionism with theological anti-Judaism by affirming:

Article 3

WE DENY THAT modern Judaism with its explicit negation of the divine person, work, and Messiahship of Jesus Christ contains within itself true knowledge of God's salvation.

WE AFFIRM THAT the biblical hope for Jewish people centers on their being restored through faith in Christ to their proper place as branches of God's olive tree from which they are at present broken off.

WE DENY THAT the historical status of the Jews as God's people brings salvation to any Jew who does not accept the claims of Jesus Christ.

Article 27

WE AFFIRM THAT the Jewish quest for a homeland with secure borders and a just peace has our support.

The political embrace of Zionism obscures the continuing theological delegitimization of Judaism. Organizations such as the International Board of Jewish Missions (IBJM) or the Chosen People Ministries blend a missionary agenda with political support of Israel, and thereby attempt to disassociate from Eurocentric Christian triumphalism and anti-Judaism. As Robert O. Smith has argued in More Desired Than Our Own Salvation: The Roots of Christian Zionism:

As Judeo-centric English Protestants manufactured apocalyptic roles for Jews banished from their societies, contemporary Christian Zionism is less concerned with flesh-and-blood Jews than with preserving its Christian theo-political hope. Concern for systems outweighs concern for persons, whether they are Israe-

\footnotetext{
${ }^{38}$ Lausanne Consultation on Jewish Evangelism, http://www.lcje.net/willowbank.html.
} 
li Jews, Arab citizens of Israel, Palestinian Muslims, Palestinian Christians, or Iranians... ${ }^{39}$

Such a theological and political stance is anti-dialogical and therefore ultimately antithetical to genuine peace making.

Progressive Christians, on the other hand, are willing to enter dialogue and renounce Christian triumphalism. Unfortunately, a proclivity for political analysis that divides the world into oppressors and oppressed, powerful and powerless parties makes progressive Christians susceptible to traditional stereotypes that paint Jews as politically nefarious and manipulative. For instance, Walter T. Davis, the editor of Zionism and the Quest for Justice in the Holy Land dismisses the "history of shame and humiliation ...engendered by Christian antiSemitism" and the Holocaust as a "central Zionist doctrine," which creates a

self-perpetuating downward spiral of anxiety among political Zionists" [who are] manipulating this fear for political advantage... In addition to fear, the Zionist movement, like other colonial movements, required collective denial of what was being done to Palestinians, a denial that may even be characterized as selfimposed blindness. ${ }^{40}$

The language of blindness, collective denial, manipulation for political gains, etc., are deeply rooted in the history of Christian contempt and are not likely to foster respect or constructive engagement in the negotiations for peace and justice in the Middle East. Any third party intervention that takes sides for un-reflected theological or political reasons becomes itself part of the problem rather than the solution. For histori-

\footnotetext{
${ }^{39}$ Robert O. Smith, More Desired Than Our Own Salvation: The Roots of Christian Zionism (New York: Oxford University Press, 2013), 195.

${ }^{40}$ Walter T. Davis and Pauline Coffman, "From 1967 to the Present: The Triumph of Revisionist Zionism," in Zionism and the Quest for Justice in the Holy Land, Donald E. Wagner and Walter T. Davis eds. (Eugene, OR: Wipf and Stock, 2014), 28-62: 57.
} 
cal reasons alone, progressive Christians ought to be scrupulously aware and critical of proposals that promise to "solve the Jewish question.”

Systems of preeminence and privilege, such as Christian triumphalism, white supremacy, and male privilege cannot simply be stopped. Instead, we should imagine antisemitism, racism, and sexism as mighty streams that seek new channels around dams that are erected by legal caveat and normative interventions. Nostra Aetate demanded the "rejection of every persecution against any man" and "hatred, persecutions, displays of anti-Semitism, directed against Jews at any time and by anyone." But this declaration has failed to trickle down, as a recent study by the German Bundestag on antisemitism in Germany found to its surprise. In 2012, Germans who attend churches-a small minority, to be sure-displayed greater susceptibility to antisemitic stereotypes than non-observant, secular Germans. Every empirical survey conducted in Germany has shown a positive correlation between church attendance and antisemitic attitudes despite the long-standing commitments to Jewish-Christian dialogue on the part of both the Roman Catholic and Protestant Church (EKD) in Germany.

These findings fall within Weaver's understanding of backlash, in which inherent inertia and conservatism among the masses resist theological leaps and revolutionary advances. Nostra Aetate, Civil Rights legislation, and the Supreme Court's decision on Roe v. Wade can be interpreted through the lens of backlash as a reaction of ordinary people who feel left behind and refuse to follow the lead of cultural and theological elites. But Weaver is also right to point out that

\footnotetext{
${ }^{41}$ See Matthias Blum, "Expertise: Katholische Kirche und Antisemitismus," Bundesarbeitsgemeinschaft Kirche und Rechtsextremismus, http://www.bagkr.de/wpcontent/uploads/blum_antisemitismus_katholisch. pdf. Also, Albert Scherr, "Expertise: Verbreitung Von Stereotypen Über Juden und Antisemitischer Vorurteile in der Evangelischen Kirche," http://www.bagkr.de/wpcontent/uploads/scherr_antisemitismus_evangelisch.pdf.
} 
elites are often left out of the backlash story, and when they do appear... elites are not formulating discourse or strategizing, they are onlookers with an eye toward anticipating public reaction, and acting accordingly. ${ }^{42}$

She further notes that

Frontlash adds another dimension to the backlash narrative because it can show how policies that usually are considered separately are actually part of same political history; developments in one domain can and do influence strategic decisions or new developments in another, ostensibly unrelated sphere. ${ }^{43}$

"Anti-Zionism," concludes Robert Wistrich in A Lethal Obsession, serves as an "indispensable cover under which prewar anti-Jewish amalgam could be resurrected." ${ }^{4}$ The rise of Zionism as a diversionary vehicle to carry forth feelings of contempt for Jews required intellectual innovation and the deliberate transfer of religious and ideological tropes. Antisemitism has jumped the borders of Christian Europe. From the first translation of the Protocol of the Elders of Zion into Arabic, distributed by the Roman Catholic community in Jerusalem on January 15, 1926, the transfer of major antisemitic tropes, such as ritual murder charges, suspicions of a Jewish world conspiracy, and racial animus can be traced back to European sources. ${ }^{45}$ The Protocols of the Elders of Zion is

${ }^{42}$ Weaver, "Frontlash,” 238.

${ }^{43}$ Ibid., 239.

${ }^{4}$ Robert Wistrich, A Lethal Obsessions (New York: Random House, 2010), 9. See also Jeffrey Herf, Nazi Propganda for the Arab World (New Haven: Yale University Press, 2009) and Barry Rubin and Wolfgang Schwanitz, Nazis, Islamists, and the Making of the Modern Middle East (New Haven: Yale University Press, 2014).

${ }^{45}$ Derek Penslar, Israel in History: The Jewish State in Comparative Perspective (New York, NY and Abingdon, ON: Routledge), 124, writes: "In the Nineteenth century, notions of a Jewish international political and financial conspiracy were exported to the Middle East, largely via French and Francophone Christian clerics." See also "Anti-Semites on Zionism: From Indifference to Obsessions," in Jeffrey Herff ed. Anti-Semitism and 
now available in sixty different translations and as a film series with forty one sequels. ${ }^{46}$ The Egyptian ministry of information hired fugitive Nazi propagandists as consultants after the war to build antizionist propaganda ministry, and its materials have since become deeply entrenched in political party platforms, educational resources, and Friday sermons across the Muslim world. ${ }^{47}$ For sure, these Christian imports combined with indigenous animosities and the Qu'ran's record of the prophet's enmity to Jews. The confluence of European Christian tropes and Islamic reinterpretation of the Qu'ran has turned into a perfect firestorm of genocidal hatred amidst massive modern political dislocation and economic discontent. As this export returns to Europe in its Islamist reincarnation, European governments and churches have seemed paralyzed and impotent to critically engage this ideology and to protect the Jewish remnant communities of Europe. ${ }^{48}$

Anti-Zionism provides ideological legitimacy to attack Jewish institutions and to harass and kill Jews in Amsterdam, Buenos Aires, Copenhagen, and Paris. It serves to intimidate and discriminate against Jewish students on U.S. campuses and is used to suspect Jews of political disloyalty and involvement in conspiracy. As an ideology it is neither capable nor interested in establishing peace between Israelis and Palestinians. Instead, it creatively generates new stereotypes that replace discredited notions of the perfidious Jews who murdered Christ and slaughtered Christian boys, of Jewish communists and Jewish rapists polluting the blood of Christian nations. Anti-Zionism is a strategic circumvention of racial and theological stereotypes, and as such, not necessary for

Ant-Zionism in Historical Perspective: Convergence and Divergence (New York: Routledge, 2007), 1-20: 13.

${ }^{46}$ Michael Küntzel, Islamischer Antisemitismus und deutsche Politik: Die Juden werden brennen, Wir werden auf ihren Gräbern tanzen (Berlin: Lit Verlag, 2007). 36.

${ }^{47}$ Michael Kiefer, Antisemitismus in den islamischen Gesellschaften: Der Palästina Konflikt und der Transfer eines Feindbildes (Düsseldorf: Bertelsmann, 2002), 93.

${ }^{18}$ Küntzel, Islamischer Antisemitismus.

SCJR 10 (2015) 
churches that preach a gospel of conversion and contempt for Judaism.

By contrast, Jewish-Christian dialogue fosters relationships and engages in theological revision in order to affirm the equality of Judaism and the dignity of the Jewish community. It is committed to the flourishing of Jewish life alongside Christianity (and Islam). This stance calls for critical solidarity with Israel and robust dialogue about political issues. But it should resist sensationalized frontlash mutations that shift Jewish-Christian relations into the arena of Middle East politics among people who lack the requisite methodological and analytic tools.

The theory of frontlash is useful to explain why feminist theologians are drawn into emotional debates over reproductive health care, scholars of Jewish-Christian dialogue are forced to take position on Middle East politics, and black and womanist theologians parse police tactics, crime statistics, and prison policy. These modifications provide political and psychological cover to reframe opposition to political and theological changes that would institutionalize the humanity of women, the dignity of descendants of slaves, and respect for Jewish difference. 